44 Joyce $E$, Hutton S, Mutsatsa S, Gibbins H, Webb E, Paul S, Robbins T, Barnes TRE. Executive dysfunction in first-episode schizophrenia and relationship to duration of untreated psychosis: the West London Study. Br J Psychiatry 2002; 181 (suppl 43): s38-44

45 Hoff AL, Sakuma M, Heydebrand G, Heydebrand G, Csernansky JG, DeLisi LE. Lack of association between duration of untreated illness and severity of cognitive and structural brain deficits at the first episode of schizophrenia. Am J Psychiatry 2000; 157: 1824-8.

46 Norman RMG, Townsend L, Malla AK. Duration of untreated psychosis and cognitive functioning in first-episode patients. Br J Psychiatry 2001; 179: $340-5$.

47 Ho BC, Alicata D, Ward J, Moser DJ, O'Leary DS, Arndt S, Andreasen NC. Untreated initial psychosis: relation to cognitive deficits and brain morphology in first-episode schizophrenia. Am J Psychiatry 2003; 160: 142-8.

48 Joyce EM, Hutton SB, Mutsatsa SH, Barnes TRE. Cognitive heterogeneity in first-episode schizophrenia. Br J Psychiatry 2005; 187: 516-22.

49 Wyatt RJ. Neuroleptics and the natural course of schizophrenia. Schizophr Bull 1991; 17: 325-51.

50 Keshavan MS, Haas GL, Kahn CE, Aguilar E, Dick EL, Schooler NR, Sweeney JA, Pettegrew JW. Superior temporal gyrus and the course of early schizophrenia: progressive, static or reversible? J Psychiatry Res 1998; 32: $161-7$
51 Lappin JM, Morgan K, Morgan C, Hutchison G, Chitnis X, Suckling J, Fearon P, McGuire PK, Jones PB, Leff J, Murray RM, Dazzan P. Gray matter abnormalities associated with duration of untreated psychosis. Schizophr Res 2006; 83: 145-53.

52 DeLisi LE, Sakuma M, Tew W, Kushner M, Hoff AL, Grimson R, Schizophrenia as a chronic active brain process: a study of progressive brain structura changes subsequent to the onset of schizophrenia. Psychiatr Res 1997; 74: 129-40.

53 Keefe RS, Seidman $\sqcup$, Christensen BK, Hamer RM, Sharma T, Sitskoorn MM, Lewine RRJ, Yurgelun-Todd DA, Gur RC, Tohen M, Tollefson GD, Sanger TM, Lieberman JA. Comparative effect of atypical and conventional antipsychotic drugs on neurocognition in first episode psychosis: a randomised double blind trial of olanzapine versus low doses of haloperidol. Am J Psychiatry 2004; 161: 985-95.

54 Addington J, Saeedi H, Addington D. Influence of social perception and social knowledge on cognitive and social functioning in early psychosis. Br J Psychiatry 2006; 189: 373-8.

55 Brekke JS, Hoe M, Long J, Green MF. How neurocognition and social cognition influence functional change during community-based psychosocial rehabilitation for individuals with schizophrenia. Schizophr Bull 2007; 33 $1247-56$

\title{
Emotion in Beethoven and his music
}

\section{François Mai}

Beethoven was the first of the romantic period composers who dominated classical music during the 19th century. He himself was a passionate man who carried his feelings on his sleeve. He had episodes of depression accompanied by suicidal ideas, and rarer episodes of elation with flights of ideas. The latter are reflected in some of his letters. He had a low frustration tolerance and at times would become so angry that he would come to blows with others such as his brother Carl, or he would throw objects at his servants. Although he never married, he had several affairs, including one with a married woman who has come to be known to posterity as 'the Unknown Beloved'. To her he wrote three love letters that are filled with affection and feeling. He much enjoyed wine and this resulted in hepatic cirrhosis that caused his premature death at the age of 56.

This moodiness is reflected in his music. The 'Marches Funébres' of his Third Symphony (Eroica) and the Piano Sonata, op. 26, no, 12, are poignant and powerful portrayals of grief and bereavement. The final movement of the String Quartet, no. 6, op. 18 (La Malinconia) has sudden and alternating changes of tempo and rhythm that depict, in musical terms, the mood changes that occur in bipolar disorder. The pace and fortissimo dynamics of both his Rondo a Capriccio for piano, op. 129 and the storm movement of his Sixth Symphony (Pastoral Symphony) beautifully (or perhaps one should also say fearfully) display anger and agitation.

Beethoven also displayed positive emotions in his music. The prime example is his rendering of Schiller's poem Ode to Joy in his Ninth symphony (Choral Symphony), where the lyrical exaltation of peace and of our common brotherhood and humanity are beautifully and powerfully rendered in musical terms. Tenderness and love shine forth in the third movement of the Piano Sonata, op. 90, no. 27, and in the wellknown Bagatelle, Für Elise. During the last eight years of his life Beethoven was almost totally deaf yet during this time he composed some of his most complex and profoundly spiritual music. His deafness forced him to turn inward for inspiration, and his music during this final period of his compositional career reflects the inner peace he had achieved despite the outward turmoil of his life. The late string quartets are a sublime portrayal of this mental attitude.

Beethoven is considered to be one of the greatest composers of all time. During most of his life he had many medical and psychological problems. He may have suffered from bipolar disorder. D. Jablow Hershman and Dr Julian Lieb in their book Manic Depression and Creativity have argued quite convincingly that Beethoven was manic depressive. His medical problems included progressive deafness that began in his late twenties, chronic alcohol dependency causing cirrhosis of the liver, lead poisoning and a chronic gastro-intestinal condition (likely irritable bowel syndrome complicated by laxative misuse). Because of the strength of his personality and knowledge of the power of his message, he was able to rise above these ailments. As he himself on occasion admitted, composing for him was therapeutic. His deafness forced him to withdraw from teaching performing and conducting, hence all his energies were focused on composition. His passionate nature is reflected in the passions of his music. We are all the beneficiaries.

François Mai Medical Adviser, Government of Canada, Professor, University of Ottawa 